VAN der Walt, J. P. \& Tscheuschner, I. T. (1956). J. gen. Microbiol. 15, 459-461

\title{
Pichia vanriji n.sp., Isolated from Soil
}

\author{
By J. P. VAN DER WALT AND IRMGARD T. TSCHEUSCHNER \\ National Chemical Research Laboratory, South African Council for Scientific \\ and Industrial Research, Pretoria, South Africa
}

SUMMARY: A new Pichia species has been isolated from soil. Its characteristic features are its large cells, the abundant formation of pseudomycelium, an early appearance of a pellicle, and the formation of four-spored asci. The species is nonfermentative and assimilates only glucose, galactose, sucrose and maltose.

In the course of a study of the yeast flora associated with surface soil two strains of an apparently undescribed Pichia species were isolated.

\section{METHODS AND RESULTS}

The following description is based on the standard procedures described by Lodder \& Kreger-van Rij (1952).

\section{Description}

Growth in malt extract. After 3 days at $25^{\circ}$ the cells are round $(2 \cdot 5-8 \cdot 8) \mu$. or oval $(2 \cdot 5-7 \cdot 5) \times(3 \cdot 1-11 \cdot 3) \mu$., single or in pairs. A dull, dry, wrinkled, creeping pellicle is formed. After 1 month a sediment is formed as well.

Growth on malt agar. After 3 days at $25^{\circ}$ the cells are round (3.1-10.0) $\mu$. or oval $(3 \cdot 1-8) \times(3 \cdot 8-13 \cdot 1) \mu$., single or in pairs. Copulating cells and asci are also present. After 1 month at $17^{\circ}$ the streak culture is greyish to yellowish white and wrinkled. The margin is fringed with pseudomycelium.

Slide cultures. A pseudomycelium of the 'mycocandida' type is abundantly formed.

Sporulation. Sporulation was observed on malt agar. A heterogeneous conjugation between a cell and its bud usually precedes ascus formation. The ascospores are round, smooth, and often contain an oil droplet. One to four spores are formed per ascus (Fig. 1).

Fermentation. Absent.

Sugar assimilation. Glucose, +; galactose, +; sucrose, +; maltose, +; lactose, - .

Ethanol as sole source of carbon. Growth occurs as a pellicle.

Assimilation of potassium nitrate. Absent.

Splitting of arbutin. Positive.

\section{DISCUSSION}

The strains are included in the genus Pichia since their vegetative reproduction is characterized in the first instance by the early formation of a dull creeping pellicle and secondly by the abundant production of a pseudomycelium. 
Within this genus no species has hitherto been described which assimilates only glucose, galactose, sucrose and maltose. Because of this significant biochemical difference the strains must consequently be regarded as representative of a new species. For this species we propose the name Pichia vanriji, in honour of Mrs N. J. W. Kreger-van Rij, mycologist at the Yeast Division of the Centraal Bureau voor Schimmelcultures in Delft.

Morphologically, Pichia vanriji is also quite distinct and its close relationship with the other members of the genus, $P$. farinosa (Lindner) Hansen and $\boldsymbol{P}$. polymorpha Klöcker, quite apparent. However, the strains possess an

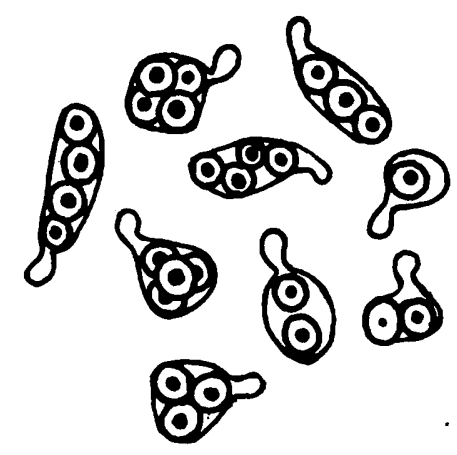

Fig. 1. Pichia vanriji. Ascospores on malt agar after 7 days. $\times 1400$.

undeniable tendency towards the formation of round cells which, in its turn, is suggestive of the genus Debaryomyces as emended by Lodder \& Kreger-van Rij (1952). These authors have, on the other hand, pointed out the close relationship between the genera Pichia and Debaryomyces and have already remarked on the existence of intermediate forms such as Debaryomyces vini Zimmermann which takes a unique intermediate place between the two genera. A culture of Pichia vanriji has been deposited in the Yeast Collection of the Central Bureau voor Schimmelcultures in Delft.

\section{LATIN DIAGNOSIS}

Pichia vanriji, sp.nov.

In musto maltato cellulae rotundae $(2 \cdot 5-8 \cdot 8) \mu$., aut ovidiae $(2 \cdot 5-7 \cdot 5)$ $\times(3 \cdot 1-11 \cdot 3) \mu$., singulae aut binae. Post dies 3 pellicula non-nitida, crispulata, sursum repens formatur. Sedimentum.

In agaro maltato cellulae rotundae $(3 \cdot 1-10) \mu$., aut ovidae $(3 \cdot 1-8 \cdot 1) \times$ $(3 \cdot 8-13 \cdot 1) \mu$., singulae aut binae. Cellulae conjugatae et asci. Cultura (post unum mensem, $17^{\circ}$ ) griseola flavalbida, crispulata, non-nitida; margine piloso. Pseudomycelium abundat.

Copulatio cellularum inaequarum plerumque conformationem asci praecedet. Ascosporae rotundae, glabrae, fortasse globulos olei continent. 1-4 in asco. 
Fermentatio nulla. In medio minerali cum glucoso, galactoso, saccharo et maltoso crescit. Nitras kalicus no assimilatur. In medio minerali cum alcohole aethylico crescit, pellicula formatur. Arbutinum finditur.

This paper is published by permission of the South African Council for Scientific and Industrial Research.

\section{REFERENCE}

Lodder, J. \& Kreger-van Riv, N. J. W. (1952). The Yeasts. Amsterdam: North Holland Publishing Company.

(Received 16 April 1956) 